\title{
Synthesis, structural investigation and biological application of new mono- and binuclear cobalt (II) mixed-ligand complexes containing 1,10-phenanthroline, acetamide and ethylenediamine
}

\author{
Getinet Tamiru $^{1, \mathrm{a},}{ }^{*}$, Atakilt Abebe ${ }^{1, \mathrm{~b}}$, Moges Abebe ${ }^{1}$, Misganaw Liyew ${ }^{2}$ \\ ${ }^{1}$ Bahir Dar University, Science College, Chemistry Department, PO Box 79, \\ Ethiopia \\ ${ }^{2}$ Bahir Dar University, Science College, Biology Department, Microbiology \\ Research Laboratory POBox79, Ethiopia \\ agetsh2007@gmail.com; ORCID: 0000-0002-1819-7222 \\ batakiltabebe1@gmail.com; ORCID: 0000-0002-5496-664X
}

\begin{abstract}
The intensive use of antibiotics has led to an increase of drug resistant bacteria against known antibiotics. To overcome the alarming problem of microbial resistance to antibiotics, the discovery of novel active compounds against new targets is a matter of urgency. Based on this, we report three new mixed ligand complexes of cobalt (II)viz. mononuclear ([Co(phen $\left.)_{2}(\mathrm{Act})\left(\mathrm{H}_{2} \mathrm{O}\right)\right] \mathrm{Cl}_{2} \cdot \mathrm{H}_{2} \mathrm{O}$ and $\left.\quad\left[\mathrm{Co}(\text { phen })_{2}(\mathrm{Act})(\mathrm{en})\right] \mathrm{Cl}_{2}\right)$, and binuclear $\left[\mathrm{Co}_{2}(\mathrm{phen})_{4}(\mathrm{Act})_{2}(\mathrm{en})\right] \mathrm{Cl}_{4}$ which were synthesized from $\mathrm{CoCl}_{2} \cdot 6 \mathrm{H}_{2} \mathrm{O}$, 1,10-phenanthroline monohydrate, acetamide and ethylenediamine. These complexes were characterized using spectroscopic (ESI-MS, ICP-OES, FT-IR, and UV-Vis), chloride determination as well as melting point and conductance measurement. Invitro antibacterial activity was also tested on two Gram positive (Staphylococcus aureus, Streptococcus pyogenes) and two Gram negative (Escherichia coli and Klebsiella pneumoniae) bacteria using disc diffusion method. The complexes performed well even against the Gram-negative bacteria. The antibacterial result was found comparable with the commercial drug Gentamicin even at lower concentration of complexes. Thus, the synthesized complexes may be considered as potential antibacterial agents after passing cytotoxicity testing.
\end{abstract}

Keywords: Mixed mono- and binuclear cobalt (II) complex, Bisintercalation, Spectroscopic studies, Antibacterial activity. DOI: https://dx.doi.org/10.4314/ejst.v12i1.4

* Corresponding author: getsh2007@gmail.com 


\section{INTRODUCTION}

The widespread use and misuse of antibiotics led to a serious public health problem due to bacterial resistance to antibiotics (Golkar et al., 2014; Ventola, 2015; Li and Webster, 2018). According to WHO (2012, 2017), great percentage of hospital-acquired infections are caused by highly resistant bacteria such as methicillin-resistant Staphylococcus aureus (MRSA) and vancomycin resistant enterococci (VRE) or others (super bacteria: Escherichia coli, Klebsiella pneumoniae, etc.). This is expressed in terms of enhanced morbidity and mortality, which makes them survive under the effects of most antibiotics currently in use. Despite the large number of antibiotics and chemotherapeutics available for medical use, parallel emergence of old and new antibiotic resistance created in the last decades revealed substantial medical need for new classes of antimicrobial agents (WHO, 2012a). Treatment of infectious diseases still remains a challenge because of a combination of factors including emerging infectious diseases and the increase in the number of multi-drug resistant microbial pathogens (WHO, 2012b; US Department of Health and Human Services, 2013).

To alleviate this problem, the discovery of novel active compounds with good spectrum of activity and new mechanisms of action against new targets is a matter of urgency (WHO, 2012b; WHO, 2018). From this perspective, the synthesis of new metal complexes and evaluation of their antibacterial activity have been considered by the global community as part of the solution (Saha et al., 2009; Rafique et al., 2010). Based on this, a good number of mononuclear (Ghatole et al., 2012; Pasdar et al., 2015; Atakilt Abebe and Tizazu Hailemariam, 2016; Atakilt Abebe and Getinet Tamiru, 2018), binuclear (Patel et al., 2009; Krishna et al., 2013; Gurumoorthy et al., 2014; Panda et al., 2015;) and metal mixed-ligand complexes have been reported in the literature. In particular, Co (II) containing mixed ligand complexes appeared promising in solving the aforementioned problems (Patel et al., 2009; Chang et al., 2010). In most of these reports, however, Co (II) complexes did not work against Gramnegative bacteria (Shalash and Ali, 2017). This is because their composition prohibited them to penetrate through the cell wall of 
these bacteria (Gao et al., 1999; Podunavac-Kuzmanović et al., 2008; Stănilă et al., 2011). These phenomena motivated us to look for a solution by synthesis and investigation of biological activities of mononuclear and binuclear mixed-ligand cobalt (II) complexes containing 1,10-phenanthroline (phen), acetamide (act) and ethylenediamine (en) combined. To our knowledge, there is no report with this composition. 1,10-Phenanthroline is rigid planar, hydrophobic, electron-poor, $\pi$-acidic, chelating bidentate ligand (Bencini and Lippolis, 2010). These properties enable it to have stacking interaction ability with DNA base pairs that its role in the preparation of medicines mainly targeting the genetic materils is of paramount importance (Chandraleka et al., 2014; Mahalakshmi and Raman, 2016). Acetamide and its derivatives are ligands containing amide moiety acting as an $\mathrm{O}-, \mathrm{N}$ - donor having a strong ability to form metal complexes and exhibit a wide range of improved biological activities (Kerridge, 1988). Medicinal chemists have carried out considerable research on amide derivatives, Penicillins and cephalosporins, which possess acetamide moiety as the side chain, are widely used antibiotics for the treatment of systemic infections (El-Reash et al., 2016; Gull, 2016). Ethylenediamine, its salts and derivatives are frequently found in drugs as well as biologically important molecules (Hast et al., 2009). The ethylenediamine portion plays an essential role in the biological activities of the molecules and the structural features of this moiety that confer biological activity are the electron distribution among the atoms and the stereochemistry (Nworie, 2016). Therefore, this study reports the synthesis, structural investigation and antimicrobial activity of new mononuclear and binuclear cobalt (II) mixed-ligand complexes of 1,10-phenanthroline, acetamide and ethylenediamine.

\section{MATERIALS AND METHODS}

\section{Chemicals}

1,10-phenanthroline monohydrate (BDH Chemical Ltd., Poole, England) ( $>99 \%)$, Acetamide ( $\sim 99 \%)$, Ethylenediamine $(>99 \%)$, $\mathrm{CoCl} 2.6 \mathrm{H} 2 \mathrm{O}(>98 \%)$, silver nitrate $(>99 \%)$, acetone $(>98 \%)$, 
acetonitrile (>98\%), chloroform (>98\%), Perchloric acid (70\%), methanol (Absolut) (all from Hi Media Laboratories Ltd., India), $\mathrm{KBr}$, dichloromethane, Mueller Hinton agar, and nitric acid (T.V. Industrial Estate, India) were used.

\section{Instruments and Methods}

The electronic conductance was measured using $10^{-4} \mathrm{M}$ solution of each complex in distilled water with JENWAY 4200 conductivity meter at room temperature. The electronic spectra were recorded in the $200-800 \mathrm{~nm}$ region on cary $60 \mathrm{UV}$-Vis spectrophotometer. Infrared (FT-IR) spectra were recorded using a Perkin Elmer spectrum BX spectrophotometer in $400-4000 \mathrm{~cm}^{-1}$ range in $\mathrm{KBr}$ pellets. HR-ESI spectra were conducted on dual ionization $\mathrm{ESCi}{ }^{\circledR}$ (ESI/APCi) source options Waters LCT Premier XE (Waters Corp., Manchester, UK) at Academia Sinica, Institute of Chemistry, Taiwan. Cobalt content in each synthesized complex was determined using Perkin Elmer, Optima 7300 VHF Version ICP-OES spectrometer, after digesting each complex in a mixture of concentrated perchloric acid and nitric acid followed by diluting with distilled water. Melting points were determined using SMP30 digital melting point apparatus. Chloride estimations were made thermogravimetrically using the $\mathrm{AgCl}$ precipitate obtained from mixture of solution of each complex in distilled water with excess $\mathrm{AgNO}_{3}$ solution (Khopkar, 1998).

\section{Synthesis}

New mono- and binuclear cobalt (II) mixed-ligand complexes containing 1,10-phenanthroline, acetamide and ethylenediamine were synthesized using different metal: ligand ratio under optimized reaction condition.

\section{Diaquabis (1,10-phenantroline) cobalt (II) chloride monohydrate $\left[\mathrm{Co}(\mathrm{Phen})_{2}\left(\mathrm{H}_{2} \mathrm{O}\right)_{2}\right] \mathrm{Cl}_{2} . \mathrm{H}_{2} \mathrm{O}$ (1)}

A solution of 1,10-phenanthroline monohydrated (1.8399 g, 9.3 mmol) in $30 \mathrm{~mL}$ methanol was added drop wise to a magnetically stirred methanolic solution of $\mathrm{CoCl}_{2} .6 \mathrm{H}_{2} \mathrm{O}(1.1043 \mathrm{~g}, 4.6 \mathrm{mmol})$ in $100 \mathrm{~mL}$ round bottom flask in water bath. The mixture was allowed to stir for $3 \mathrm{~h}$ at room temperature and the reaction progress was 
monitored by TLC. Light-pink homogeneous solution was obtained. The solvent was removed using rotary evaporator. Light-pink powder was collected and washed three times with acetone to remove any unreacted 1,10-phenanthroline. Then, it was recrystallized from methanol.

Yield: (2.4827 g, 98\%); FT-IR (KBr pellet, $\left.\mathrm{cm}^{-1}\right)$ : 3410 vo-H, 1518 $\mathrm{v}_{\mathrm{C}=\mathrm{N}}$; UV-Vis (Methanol, $\left.\mathrm{nm}\right): 227 \pi \rightarrow \pi^{*}(\mathrm{C}=\mathrm{C}), 268 \mathrm{n} \rightarrow \pi^{*}(\mathrm{C}=\mathrm{N})$, 442, 635, 744 (d-d transition bands); ESI MS (Methanol, $\mathrm{m} / \mathrm{z}$ ):calcd for $\left[\mathrm{Co}(\mathrm{Phen})_{2}\left(\mathrm{H}_{2} \mathrm{O}\right)_{2}-\mathrm{H}^{-}\right]$: $454.31[\mathrm{M}-\mathrm{H}]$; found: 453.93 .

Aquaacetamide ethylene diaminebis (1,10-phenantroline) cobalt (II) chloride monohydrate $\left[\mathrm{Co}(\mathrm{Phen})_{2}(\mathrm{act})\left(\mathrm{H}_{2} \mathrm{O}\right)\right] \mathrm{Cl}_{2} \cdot \mathrm{H}_{2} \mathrm{O}$ (2)

To a methanolic solution of $\left[\mathrm{Co}(\text { phen })_{2}\left(\mathrm{H}_{2} \mathrm{O}\right)_{2}\right] \mathrm{Cl}_{2} \mathrm{H}_{2} \mathrm{O}(1.0026 \mathrm{~g}, 1.8$ $\mathrm{mmol})$ in $100 \mathrm{~mL}$ round bottom flask and magnetically stirred in water bath, a solution of acetamide $(0.1099 \mathrm{~g}, 1.9 \mathrm{mmol})$ in $30 \mathrm{~mL}$ methanol was added from a dropping funnel. Then, the mixture was refluxed for $1 \mathrm{~h}$ at $50-60^{\circ} \mathrm{C}$ via TLC monitoring. The mixture was kept overnight to cool to room temperature. Then, the solvent was removed under vacuum at room temperature and the powder was recrystallized from methanol. Deep-pink powder was collected.

Yield: (0.8291 g, 79\%); FT-IR (KBr pellet, $\left.\mathrm{cm}^{-1}\right): 3448$ (s, br) vo-H, $3448\left(\mathrm{~s}\right.$, br) $\mathrm{v}_{\mathrm{N}-\mathrm{H}}, 1545 \mathrm{v}_{\mathrm{C}=\mathrm{N}}, 1661 \mathrm{v}_{\mathrm{C}=\mathrm{O}}$; UV-Vis (Methanol, nm): 232 $\pi \rightarrow \pi^{*}(\mathrm{C}=\mathrm{C}), 269 \mathrm{n} \rightarrow \pi^{*}(\mathrm{C}=\mathrm{N}), 447,627,753$ (d-d transition bands).

\section{Acetamidebis (1,10-phenantroline) cobalt (II)- $\mu$-ethylene diamine acetamidebis $(1,10$-phenantroline) cobalt (II) chloride $\left[\mathrm{Co}_{2}(\text { phen })_{4}(\mathrm{Act})_{2}(\mathrm{en})\right]_{\mathrm{Cl}}$ (3)}

A solution of ethylene diamine $(66.78 \mu \mathrm{L}, 1 \mathrm{mmol})$ in $30 \mathrm{~mL}$ methanol was added from a dropping funnel to a methanol solution of $\left[\mathrm{Co}(\mathrm{Phen})_{2}(\mathrm{act})\left(\mathrm{H}_{2} \mathrm{O}\right)\right] \mathrm{Cl}_{2} \mathrm{H}_{2} \mathrm{O}(1.1710 \mathrm{~g}, 2.0 \mathrm{mmol})$ being stirred in $100 \mathrm{~mL}$ round bottom flask in a water bath at room temperature. The reaction progress was monitored by TLC and the mixture was further refluxed for additional $1 \mathrm{~h}$ at $50-60^{\circ} \mathrm{C}$ resulting in Redishbrown solution. It was left to stand overnight to cool to room temperature. The solvent was removed under vacuum at room temperature and reddish-brown powder was collected, washed with acetone and dried. 
Yield: (1.1360 g, 98\%); FT-IR (KBr pellet, $\left.\mathrm{cm}^{-1}\right): 3436 \& 3206 \mathrm{v}_{\mathrm{N}-\mathrm{H}}$, $1520 \mathrm{v}_{\mathrm{C}=\mathrm{N}}, 1648 \mathrm{v}_{\mathrm{C}=\mathrm{O}}$; UV-Vis (Methanol, nm): $227 \pi \rightarrow \pi^{*}(\mathrm{C}=\mathrm{C}), 272$ $\mathrm{n} \rightarrow \pi^{*}(\mathrm{C}=\mathrm{N}), 456,540,733$ (d-d transition bands); ESI MS (Methanol, m/z):calcd for $\left[\mathrm{Co}_{2}(\mathrm{Phen})_{4}(\text { Act })_{2}(\mathrm{en})\right]^{4+}: 1017.05[\mathrm{M}+]$; found: 1016.71

\section{Acetamide ethylene diaminebis (1,10-phenantroline) cobalt (II) chloride $\left[\mathrm{Co}(\mathrm{phen})_{2}(\mathrm{Act})(\mathrm{en})\right] \mathrm{Cl}_{2}(4)$}

To a methanolic solution of $\left[\mathrm{Co}(\mathrm{Phen})_{2}(\mathrm{act})\left(\mathrm{H}_{2} \mathrm{O}\right)\right] \mathrm{Cl}_{2} \mathrm{H}_{2} \mathrm{O}(0.5855$ $\mathrm{g}, 1.0 \mathrm{mmol})$ in $100 \mathrm{~mL}$ round bottomed flask stirred magnetically in a water bath at room temperature, a solution of ethylene diamine $(66.78 \mu \mathrm{L}, 1 \mathrm{mmol})$ in $20 \mathrm{~mL}$ methanol was added from a dropping funnel. The mixture was allowed to stir for $1: 30 \mathrm{~h}$ and it was further refluxed for $1 \mathrm{~h}$ at $50-60^{\circ} \mathrm{C}$ via TLC monitoring. Then it was kept overnight to cool to room temperature. Yellowish precipitate was formed. The precipitate was filtered and washed with acetone and dried).

Yield: (0.5912 g, 97\%); FT-IR (KBr pellet, $\left.\mathrm{cm}^{-1}\right): 3506 \& 3206 \mathrm{v}_{\mathrm{N}-\mathrm{H}}$, $1557 \mathrm{v}_{\mathrm{C}=\mathrm{N}}, 1649 \mathrm{v}_{\mathrm{C}=\mathrm{O}}$; UV-Vis (Methanol, $\left.\mathrm{nm}\right): 212 \pi \rightarrow \pi^{*}(\mathrm{C}=\mathrm{C})$, $274 \mathrm{n} \rightarrow \pi^{*}(\mathrm{C}=\mathrm{N}), 466,634,751$ (d-d transition bands); ESI MS (Methanol, $\mathrm{m} / \mathrm{z}$ ): calcd for $\left[\mathrm{Co}(\mathrm{Phen})_{2}(\mathrm{Act})(\mathrm{en})-\mathrm{H}^{-}\right]$: 537.49: found: 537.53.

\section{Antibacterial activity testing}

The ligands1,10-phenanthroline (phen), acetamide (act) and ethylenediamine (en) and their metal complexes (1), (2), (3) and (4) were evaluated for in vitro antibacterial activities against strains of two Gram-positive Staphylococcus aureus (S. aureus and Streptococcus pyogenes (S. pyogenes) and two Gram-negative Escherichia coli (E. coli) and Klebsiella pneumoniae (K. pneumonia) bacteria. They were investigated by disc diffusion methods. Muller Hinton agar (MHA) and nutrient Blood agar (BA) were used for culturing the bacterial isolates while diagnostic sensitivity test agar (Oxoid Ltd BASINGSTOK England) was used for sensitivity. The bacterial strains were maintained in the appropriate blood agar base at $4^{\circ} \mathrm{C}$. Antibiotic discs gentamicin was used as reference. The minimum inhibitory concentration (MIC) against each bacterium was determined by preparing aqueous solutions of different 
concentrations of the complexes by serial dilution (100, 200, 300, 400,500 and $600 \mathrm{mg} / \mathrm{L}$ ). The experiments were repeated three times to ascertain consistency in results. The antibacterial tests were carried out at Bahir Dar University, Department of Biology, Microbiology Laboratory, Bahir Dar, Ethiopia.

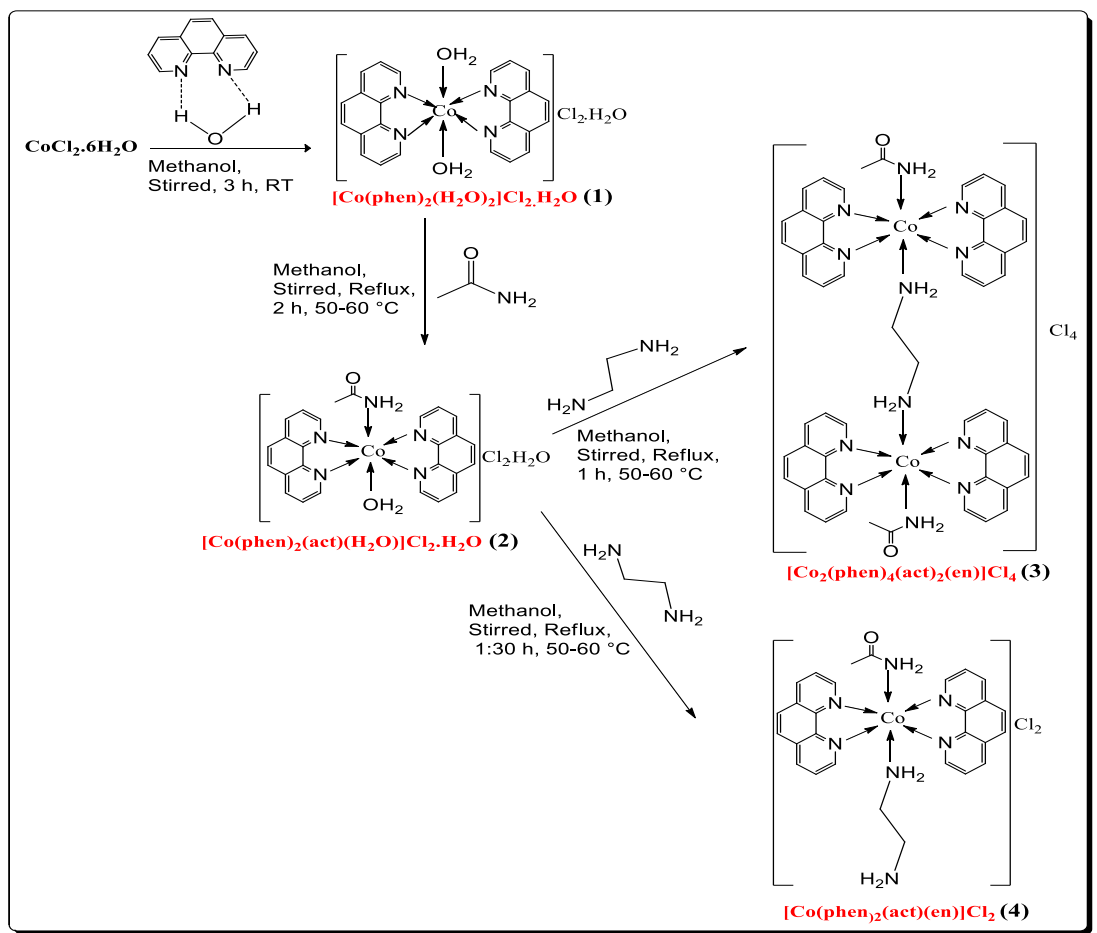

Scheme 1: Synthesis path of the Co (II)-complexes 


\section{RESULTS AND DISCUSSION}

\section{Physical characterization of Co (II) complexes}

The salts (1), (2), (3) and (4) were stable in air. They were soluble in water, methanol, ethanol, acetonitrile, and DMSO. The analytical data of the complexes were in agreement with the assigned formulae (Table 1) (Saha et al., 2009).

Molal conductance of the metal complexes. The conductance measurements, recorded for $10^{-4} \mathrm{M}$ solutions of the metal complexes in deionized water, are listed in Table 1 . The result confirmed the strong electrolytic nature of the complexes and the cation: anion ratios are in agreement with the proposed structure of both mono- and binuclear Co(II) complexes. Nevertheless, the conductivity of the binuclear complex, $\left[\mathrm{Co}_{2}(\mathrm{Phen})_{4}(\mathrm{Act})_{2}(\mathrm{en})\right] \mathrm{Cl}_{4}$, was lower than that of corresponding mononuclear complex $\left[\mathrm{Co}(\mathrm{Phen})_{2}(\mathrm{Act})(\mathrm{en})\right] \mathrm{Cl}_{2 .}$ This is a consequence of increase in molar mass, surface area andhydration as a result of increase in the charge of the cation. Hence, the speed of cation mobility decreases due to the decrease in the kinetic energy imparted by the electric field from measurement instrument (Refat $e t$ al., 2013).

\section{FT-IR spectroscopy}

The infrared spectra, selected characteristic frequencies of the ligands and the complexes are listed in Table 2. The characteristic stretching bands in free ligand 1,10-phenanthroline monohydrate at $1635 \mathrm{~cm}^{-1}$ (s), $1584 \mathrm{~cm}^{-1}$ (s) and $3437 \mathrm{~cm}^{-1}$ (s) due to $v_{\mathrm{C}=\mathrm{C}}, v_{\mathrm{C}=\mathrm{N}}$ and $v_{\mathrm{O}-\mathrm{H}}\left(\mathrm{H}_{2} \mathrm{O}\right)$, respectively, shifted to $1621 \mathrm{~cm}^{-1}(\mathrm{~s}), 1518 \mathrm{~cm}^{-1}(\mathrm{~s})$ and $3410 \mathrm{~cm}^{-1}$ (s, br) in $\left[\mathrm{Co}(\mathrm{Phen})_{2}\left(\mathrm{H}_{2} \mathrm{O}\right)_{2}\right] \mathrm{Cl}_{2} \mathrm{H}_{2} \mathrm{O}$, indicated coordination of $1,10-$ phenanthroline. The broadness of the band at $3410 \mathrm{~cm}^{-1}$ ( $\mathrm{s}$ and $\mathrm{b}$ ) in $\left[\mathrm{Co}(\mathrm{Phen})_{2}\left(\mathrm{H}_{2} \mathrm{O}\right)_{2}\right] \mathrm{Cl}_{2} . \mathrm{H}_{2} \mathrm{O}$ is presumably due to increasing in the number and type (coordinated and crystallization) of water molecules (Figure 1a \& d). 
Table 1. Physical characteristics of Co (II) complexes

\begin{tabular}{|c|c|c|c|c|c|c|}
\hline \multirow[t]{2}{*}{ Complex /color } & \multirow{2}{*}{$\begin{array}{l}\text { Molecular } \\
\text { weight } \\
\text { (g/mol) }\end{array}$} & \multirow[t]{2}{*}{ Melting point $\left({ }^{\circ} \mathrm{C}\right)$} & \multirow[t]{2}{*}{$\begin{array}{l}\text { Yield } \\
\text { (\%) }\end{array}$} & \multicolumn{2}{|c|}{$\begin{array}{l}\text { Elemental estimation } \\
\text { calculated (found) (\%) }\end{array}$} & \multirow{2}{*}{$\begin{array}{l}\text { Molar } \\
\text { conductivity } \\
\mathbf{\Lambda M} \\
\left(\mathbf{S c m}^{2} \mathbf{m o l}^{-1}\right)\end{array}$} \\
\hline & & & & Co & $\mathrm{Cl}$ & \\
\hline $\begin{array}{l}{\left[\mathrm{Co}(\text { phen })_{2}\left(\mathrm{H}_{2} \mathrm{O}\right)_{2}\right] \mathrm{Cl}_{2} \cdot \mathrm{H}_{2} \mathrm{O}} \\
\text { Lightpink }\end{array}$ & 544.41 & $>228$ (decompose) & 98 & $2.8(2.8)$ & $13.0(13.0)$ & 243.8 \\
\hline $\begin{array}{l}{\left[\mathrm{Co}(\text { phen })_{2}(\mathrm{act})\left(\mathrm{H}_{2} \mathrm{O}\right)\right] \mathrm{Cl}_{2} \cdot \mathrm{H}_{2} \mathrm{O}} \\
\text { Deep-pink }\end{array}$ & 585.47 & $>314$ (decompose) & 79 & $3.2(3.2)$ & $12.1(12.0)$ & 357.1 \\
\hline $\begin{array}{l}{\left[\mathrm{Co}_{2}(\mathrm{Phen})_{4}(\mathrm{Act})_{2}(\mathrm{en})\right] \mathrm{Cl}_{4}} \\
\text { Redish-brown }\end{array}$ & 1159.15 & 95-97 (melt) & 98 & $4.1(3.9)$ & $12.3(12.2)$ & 543.4 \\
\hline $\begin{array}{l}{\left[\mathrm{Co}(\text { phen })_{2}(\mathrm{act})(\mathrm{en})\right] \mathrm{Cl}_{2}} \\
\text { Yellow-violet }\end{array}$ & 609.49 & $256-258$ (melt) & 97 & $9.7(9.4)$ & $11.7(11.5)$ & 629.8 \\
\hline
\end{tabular}


Table 2. Charcteristic vibration frequence of ligands and complexes

\begin{tabular}{|c|c|c|c|c|c|c|c|c|c|}
\hline \multirow[t]{2}{*}{ Compound } & \multicolumn{9}{|c|}{ Absorption frequencies $\left(\mathrm{cm}^{-1}\right)$} \\
\hline & $\mathbf{v}_{\mathrm{O}-\mathrm{H}}$ & $\mathbf{v}_{\mathrm{N}-\mathrm{H}}$ & $\mathbf{v}_{\mathrm{C}-\mathrm{H}}$ & $\mathbf{v}_{\mathrm{C}=\mathrm{C}}$ & $\mathbf{v}_{\mathbf{C}=\mathbf{N}}$ & $\mathbf{v}_{\mathrm{C}-\mathrm{N}}$ & $\mathbf{v}_{\mathbf{C}=\mathbf{O}}$ & $\mathbf{V}_{\mathrm{C} 0-\mathrm{O}}$ & $\mathbf{v}_{\mathrm{C} 0-\mathrm{N}}$ \\
\hline 1,10-phenanthroline & 3437 & - & 3029 & 1635 & 1589 & 1328 & - & - & - \\
\hline Acetamide & - & $\begin{array}{l}3372 \\
3194\end{array}$ & 2809 & - & - & 1390 & 1672 & - & - \\
\hline Ethylenediamine & - & $\begin{array}{l}3424 \\
3337\end{array}$ & 2925 & - & - & 1314 & - & - & - \\
\hline$\left[\mathrm{Co}(\mathrm{Phen})_{2}\left(\mathrm{H}_{2} \mathrm{O}\right)_{2}\right] \mathrm{Cl}_{2 .} \mathrm{H}_{2} \mathrm{O}$ & 3410 & - & 3040 & 1621 & 1518 & 1341 & - & 642 & 510 \\
\hline$\left[\mathrm{Co}(\mathrm{Phen})_{2}(\mathrm{Act})\left(\mathrm{H}_{2} \mathrm{O}\right)\right] \mathrm{Cl}_{2} \cdot \mathrm{H}_{2} \mathrm{O}$ & $3448(\mathrm{~s}, \mathrm{br})$ & $3448(\mathrm{~s}, \mathrm{br})$ & & 1621 & 1545 & 1403 & 1661 & 637 & 548 \\
\hline$\left[\mathrm{Co}_{2}(\mathrm{Phen})_{4}(\mathrm{Act})_{2}(\mathrm{en})\right] \mathrm{Cl}_{4}$ & - & $\begin{array}{l}3436 \\
3206\end{array}$ & & 1621 & 1520 & 1405 & 1648 & - & 580 \\
\hline$\left[\mathrm{Co}(\mathrm{Phen})_{2}(\mathrm{Act})(\mathrm{en})\right] \mathrm{Cl}_{2}$ & - & $\begin{array}{l}3506 \\
3206\end{array}$ & 2964 & 1621 & 1557 & 1410 & 1649 & - & 580 \\
\hline
\end{tabular}


The coordination of acetamide to $\left[\mathrm{Co}(\mathrm{Phen})_{2}\left(\mathrm{H}_{2} \mathrm{O}\right)_{2}\right] \mathrm{Cl}_{2} \mathrm{H}_{2} \mathrm{O}$ to obtain $\left[\mathrm{Co}(\mathrm{Phen})_{2}(\mathrm{Act})\left(\mathrm{H}_{2} \mathrm{O}\right)\right] \mathrm{Cl}_{2} \mathrm{H}_{2} \mathrm{O}$ was confirmed from the appearance of new band at $1672 \mathrm{~cm}^{-1}(\mathrm{~s})$ characteristic for $v_{\mathrm{C}=\mathrm{O}}$, in addition to the shifts observed on the characteristic absorption frequencies of the former complex. However, the characteristic N-H $\left(\mathrm{NH}_{2}\right)$ stretching band in free acetamide disappeared from the complex which indicated that it is coordinated to Co (II) via its amine nitrogen (Figure 1e). The coordination of ethylenediamine to $\left[\mathrm{Co}(\mathrm{Phen})_{2}(\mathrm{Act})\left(\mathrm{H}_{2} \mathrm{O}\right)\right] \mathrm{Cl}_{2} \mathrm{H}_{2} \mathrm{O}$ to get $\left[\mathrm{Co}(\mathrm{Phen})_{2}(\mathrm{act})(\mathrm{en})\right] \mathrm{Cl}_{2}$ is confirmed by the appearance of new bands at $3512 \mathrm{~cm}^{-1}(\mathrm{~s}, \mathrm{~b})$ and $3206 \mathrm{~cm}^{-1}(\mathrm{~s})$ which are characteristic to stretching frequencies of $v_{\mathrm{N}}$ $\mathrm{H}\left(\mathrm{NH}_{2}\right)$. However, the latter bands disappeared in $\left[\mathrm{Co}_{2}(\mathrm{Phen})_{4}(\mathrm{act})_{2}(\mathrm{en})\right] \mathrm{Cl}_{4}$ which is most probably because the second nitrogen is involved in the coordination to Co (II). The latter is a good confirmation for the formation of the binuclear complex (Atkins,1994; Housecraft and Sharpe, 2005; Tigineh and Liu, 2014).

\section{Electronic absorption spectra}

The spectral data of the compounds in methanol are presented in Figure 2 and Table 3. The two absorption bands at in the ultraviolet region, namely 232, $264 \mathrm{~nm}$, in Figure $2 \mathrm{a}$ assigned to $\mathrm{n} \rightarrow \pi^{*}(\mathrm{C}=\mathrm{N})$ and $\pi \rightarrow \pi^{*}(\mathrm{C}=\mathrm{C})$ transitions for molecular 1,10-phenanthroline appeared shifted towards $227,268 \mathrm{~nm}$ in $\left[\mathrm{Co}(\mathrm{Phen})_{2}\left(\mathrm{H}_{2} \mathrm{O}\right)_{2}\right] \mathrm{Cl}_{2} \cdot \mathrm{H}_{2} \mathrm{O}$. Furthermore, the latter absorption bands appeared towards lower and higher frequencies, confirming the coordination of the other ligands to the metallic ions to give $\left[\mathrm{Co}(\mathrm{Phen})_{2}(\mathrm{act})\left(\mathrm{H}_{2} \mathrm{O}\right)\right] \mathrm{Cl}_{2} \quad . \mathrm{H}_{2} \mathrm{O}$, $\left[\mathrm{Co}(\mathrm{Phen})_{2}(\mathrm{act})(\mathrm{en})\right] \mathrm{Cl}_{2}$ and $\left[\mathrm{Co}_{2}(\mathrm{Phen})_{4}(\mathrm{act})_{2}(\mathrm{en})\right] \mathrm{Cl}_{4}$.

The visible electronic absorption spectrum of the cobalt (II) complex is dominated by the ${ }^{4} \mathrm{~T}_{1 \mathrm{~g}}(\mathrm{~F}) \rightarrow{ }^{4} \mathrm{~T}_{1 \mathrm{~g}}(\mathrm{P}),{ }^{4} \mathrm{~T}_{1 \mathrm{~g}}(\mathrm{~F}) \rightarrow{ }^{4} \mathrm{~A}_{2 \mathrm{~g}}(\mathrm{~F})$ and ${ }^{4} \mathrm{~T}_{1 \mathrm{~g}}(\mathrm{~F}) \rightarrow{ }^{4} \mathrm{~T}_{2 \mathrm{~g}}(\mathrm{~F})$ transition, which is a typical one for octaedral Co (II) complexes (Iniama and Iorkpiligh, 2013; Bharathi Krishnan, 2016).

\section{MS spectroscopy}

The ESI MS spectrum of the complexes recorded dissolving in methanol showed characteristic molecular ion peaks at $\mathrm{M} / \mathrm{z}=453.93$, 
537.53, and 1016.71 corresponding to $\left[\mathrm{Co}(\mathrm{Phen})_{2}\left(\mathrm{H}_{2} \mathrm{O}\right)_{2}-\mathrm{H}^{-}\right]$, $\left[\mathrm{Co}(\mathrm{Phen})_{2}(\mathrm{Act})(\mathrm{en})-\mathrm{H}^{-}\right]$and $\left[\mathrm{Co}_{2}(\mathrm{Phen})_{4}(\mathrm{Act})_{2}(\mathrm{en})\right]^{4+}$, respectively (Figure 3a-c). This characterization compounded the evidences found in the former techniques in confirming the achievement of the intended complexes.

Table 3. Electronic spectral data of the salt and complexes

\begin{tabular}{|c|c|c|}
\hline Compounds & $\begin{array}{l}\text { Absorption bands } \\
\text { (nm) }\end{array}$ & Assignments \\
\hline 1,10-phenantroline & 232,264 & 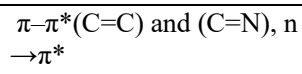 \\
\hline Acetamide & 261,280 & $\pi-\pi^{*}(\mathrm{C}=\mathrm{O}), \mathrm{n} \rightarrow \pi^{*}$ \\
\hline Ethylene diamine & 289 & $\mathrm{n} \rightarrow \pi^{*}$ \\
\hline $\mathrm{CoCl}_{2} \cdot 6 \mathrm{H}_{2} \mathrm{O}$ & $239,331,427$ & d-d transitions bands \\
\hline$\left[\mathrm{Co}(\mathrm{Phen})_{2}\left(\mathrm{H}_{2} \mathrm{O}\right)_{2}\right] \mathrm{Cl}_{2 .} \mathrm{H}_{2} \mathrm{O}$ & $\begin{array}{l}227,268 \\
442 \\
635 \\
744\end{array}$ & $\begin{array}{l}\pi \rightarrow \pi^{*}(\mathrm{C}=\mathrm{C}), \\
\mathrm{n} \rightarrow \pi^{*}(\mathrm{C}=\mathrm{N}) \\
{ }^{4} \mathrm{~T}_{1 \mathrm{~g}(\mathrm{~F})} \rightarrow{ }^{4} \mathrm{~T}_{1 \mathrm{~g}(\mathrm{P})} \\
\left.{ }^{4} \mathrm{~T}_{1 \mathrm{~g}(\mathrm{~F})} \rightarrow{ }^{4} \mathrm{~A}_{2 \mathrm{~g}(\mathrm{~F}}\right) \\
{ }^{4} \mathrm{~T}_{1 \mathrm{~g}(\mathrm{~F})} \rightarrow{ }^{4} \mathrm{~T}_{2 \mathrm{~g}(\mathrm{~F})}\end{array}$ \\
\hline $\begin{array}{l}{\left[\mathrm{Co}(\mathrm{Phen})_{2}(\mathrm{act})\left(\mathrm{H}_{2} \mathrm{O}\right)\right] \mathrm{Cl}_{2}} \\
. \mathrm{H}_{2} \mathrm{O}\end{array}$ & $\begin{array}{l}232,269 \\
447 \\
627 \\
753\end{array}$ & $\begin{array}{l}\pi \rightarrow \pi^{*}(\mathrm{C}=\mathrm{C}), \\
\mathrm{n} \rightarrow \pi^{*}(\mathrm{C}=\mathrm{N}) \\
{ }^{4} \mathrm{~T}_{1 \mathrm{~g}(\mathrm{~F})} \rightarrow{ }^{4} \mathrm{~T}_{1 \mathrm{~g}(\mathrm{P})} \\
\left.{ }^{4} \mathrm{~T}_{1 \mathrm{~g}(\mathrm{~F})} \rightarrow{ }^{4} \mathrm{~A}_{2 \mathrm{~g}(\mathrm{~F}}\right) \\
{ }^{4} \mathrm{~T}_{1 \mathrm{~g}(\mathrm{~F})} \rightarrow{ }^{4} \mathrm{~T}_{2 \mathrm{~g}(\mathrm{~F})}\end{array}$ \\
\hline$\left[\mathrm{Co}_{2}(\mathrm{Phen})_{4}(\mathrm{act})_{2}(\mathrm{en})\right] \mathrm{Cl}_{4}$ & $\begin{array}{l}227,272 \\
456 \\
540 \\
733\end{array}$ & $\begin{array}{l}\pi \rightarrow \pi^{*}(\mathrm{C}=\mathrm{C}), \\
\mathrm{n} \rightarrow \pi^{*}(\mathrm{C}=\mathrm{N}) \\
{ }^{4} \mathrm{~T}_{\mathrm{gg}(\mathrm{F})} \rightarrow{ }^{4} \mathrm{~T}_{1 \mathrm{~g}(\mathrm{P})} \\
\left.{ }^{4} \mathrm{~T}_{1 \mathrm{~g}(\mathrm{~F})} \rightarrow{ }^{4} \mathrm{~A}_{2 \mathrm{~g}(\mathrm{~F})}\right) \\
{ }^{4} \mathrm{~T}_{1 \mathrm{~g}(\mathrm{~F})} \rightarrow{ }^{4} \mathrm{~T}_{2 \mathrm{~g}(\mathrm{~F})}\end{array}$ \\
\hline$\left[\mathrm{Co}(\text { Phen })_{2}\right.$ (act)(en) $] \mathrm{Cl}_{2}$ & $\begin{array}{l}212,274 \\
466 \\
634 \\
751\end{array}$ & $\begin{array}{l}\pi \rightarrow \pi^{*}(\mathrm{C}=\mathrm{C}), \\
\mathrm{n} \rightarrow \pi^{*}(\mathrm{C}=\mathrm{N}) \\
{ }^{4} \mathrm{~T}_{1 \mathrm{~g}(\mathrm{~F})} \rightarrow{ }^{4} \mathrm{~T}_{1 \mathrm{~g}(\mathrm{P})} \\
\left.{ }^{4} \mathrm{~T}_{1 \mathrm{~g}(\mathrm{~F})} \rightarrow{ }^{4} \mathrm{~A}_{2 \mathrm{~g}(\mathrm{~F}}\right) \\
{ }^{4} \mathrm{~T}_{1 \mathrm{~g}(\mathrm{~F})} \rightarrow{ }^{4} \mathrm{~T}_{2 \mathrm{~g}(\mathrm{~F})}\end{array}$ \\
\hline
\end{tabular}

\section{Structural investigation}

The molar conductivity values of the complexes revealed that they were electrolytic in nature implying that the chloride ions were not in coordination sphere of complexes. The $\% \mathrm{Cl}$ was determined gravimetrically using aqueous solution of $\mathrm{AgNO}_{3}$ and $\% \mathrm{Co}$ was obtained via ICP-OES after digesting the complexes in strong acid followed by dilution which agreed with the theoretical values of 
chloride and metal estimation, respectively, and that meant that the proposed formula of complexes was achieved.

The observed shifts in band position and appearance of new nonligand bands in the complexes infrared spectra confirmed the successful coordination of ligands to metal center in the corresponding complexes. The UV-Visible spectra verified an electronic redistribution and change in band appearance of $\mathrm{d}-\mathrm{d}$ transition, additionally supported formation of complexes. The three $\mathrm{d} \rightarrow \mathrm{d}$ transitions resulting from $\left[{ }^{4} \mathrm{~T}_{1 \mathrm{~g}(\mathrm{~F})} \rightarrow{ }^{4} \mathrm{~T}_{2 \mathrm{~g}(\mathrm{~F})}\right],\left[{ }^{4} \mathrm{~T}_{1 \mathrm{~g}(\mathrm{~F})} \rightarrow{ }^{4} \mathrm{~A}_{2 \mathrm{~g}(\mathrm{~F})}\right]$ and $\left[{ }^{4} \mathrm{~T}_{\mathrm{lg}(\mathrm{F})} \rightarrow{ }^{4} \mathrm{~T}_{1 \mathrm{~g}(\mathrm{P})}\right]$ for all the complexes confirming an octahedral structure as reported in many octahedral cobalt (II) complexes (Iniama and Iorkpiligh, 2013; Bharathi Krishnan, 2016). Furthermore, the ESI-MS results of complexes being in an excellent agreement with the molecular weight of proposed structures of Co (II)-complexes further confirmed the composition and in turn the proposed structures of Co (II)-complexes (Scheme1).

\section{In vitro antimicrobial activity}

This experiment showed that the complexes were biologically active against all tested bacteria. The observed increase in antibacterial activity compared to the ligands could be explained on the basis of Overton's concept (Anjaneyulu and Rao, 1986) and Tweedy's chelation theory (Tweedy, 1964).

An important condition for antimicrobial activity of a compound is its ability to pass through the lipid membrane that surrounds the cell. On coordination, the polarity of the metal ion will be reduced to a greater extent due to the overlap of the ligand orbitals and partial sharing of the positive charge of the metal ion with the donor groups which significantly increases the lipophilicity of the complex. This increased liposolubility enhances the penetration of the complexes into the lipid membrane and interferes with the normal activities of the bacteria (Tweedy, 1964; Anjaneyulu and Rao, 1986; PodunavacKuzmanović et al., 2008; Warra, 2011; Al-Resayes et al., 2016). 

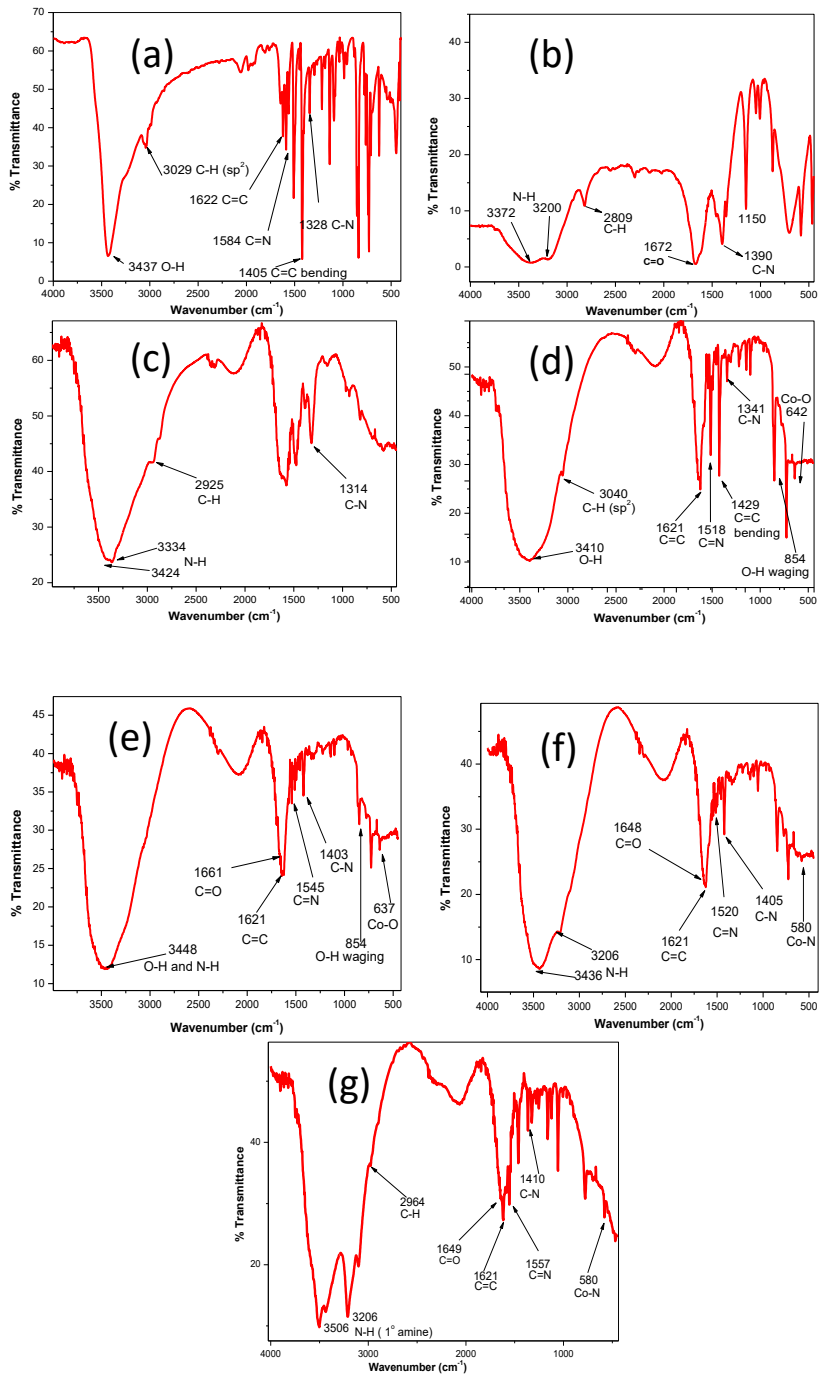

Figure 1. FTIR spectra of (a) 1,10-phenanthroline monohydrate, (b) Acetamide, (c) Ethylenediamine, (d) $\left[\mathrm{Co}(\mathrm{Phen})_{2}\left(\mathrm{H}_{2} \mathrm{O}\right)_{2}\right] \mathrm{Cl}_{2} . \mathrm{H}_{2} \mathrm{O}(1)$, (e) $\left[\mathrm{Co}(\mathrm{Phen})_{2}\right.$ (Act) $\left.\left(\mathrm{H}_{2} \mathrm{O}\right)\right] \mathrm{Cl}_{2} \cdot \mathrm{H}_{2} \mathrm{O}(2)$, (f) $\left[\mathrm{Co}_{2} \text { (Phen) }\right)_{4}(\mathrm{Act})_{2}$ (en) $] \mathrm{Cl}_{4}(3)$, (g) $\left[\mathrm{Co}(\mathrm{Phen})_{2}\right.$ (Act)(en) $] \mathrm{Cl}_{2}(4)$. 
Minimum Inhibitory Concentration (MIC) Determination: MIC is the lowest concentration that completely inhibited the growth of microorganisms for 24 hours. The MIC of $\left[\mathrm{Co}(\mathrm{Phen})_{2}(\mathrm{Act})\left(\mathrm{H}_{2} \mathrm{O}\right)\right] \mathrm{Cl}_{2} \mathrm{H}_{2} \mathrm{O}$ was found to be $100 \mu \mathrm{g} / \mathrm{L}$. Compared to the two newly synthesized mononuclear mixed ligand complexes, the new binuclear mixed ligand complex showed the greatest activity and the result obtained was even better than the antimicrobial activity of commercially available drug Gentamicin (Table 4, Figure 4).

Table 4. Results of the disc diffusion method of the metal salt, ligands and its
metal complexes

The high antimicrobial activity of the binuclear mixed ligand complex is probably because of bisintercalation due to the two planar intercalating phenanthroline ring systems covalently linked via ethylenediamine. Furthermore, configurational freedom through the bridge presumably enhanced its flexibility and in turn the penetration power of the complex (Feng et al., 2017). All complexes were found water soluble indicating their compatibility with normal human physiological systems and their potential for human medication after in vivo cytotoxicity tests. 

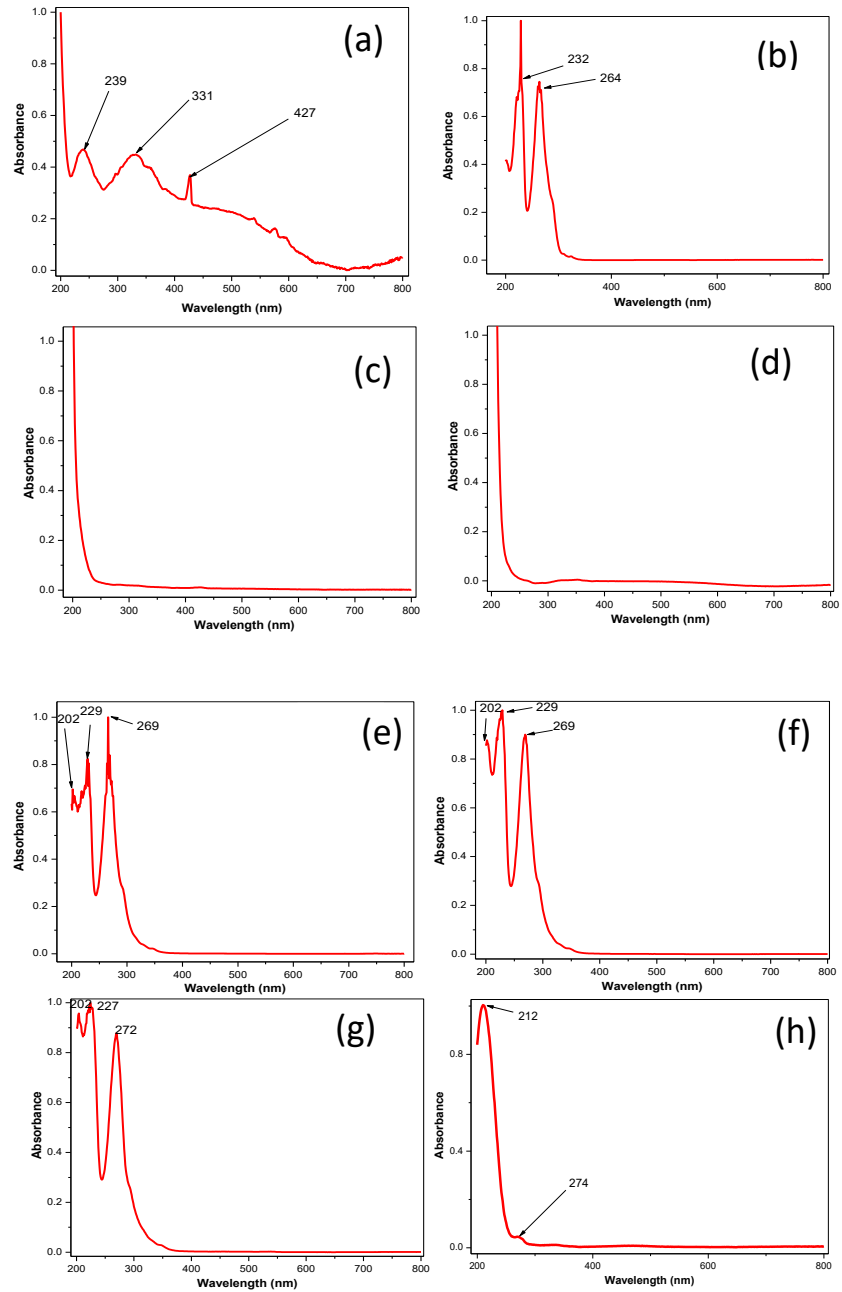

Figure 2. UV-Vis spectra of (a) $\mathrm{CoCl}_{2} \cdot 6 \mathrm{H}_{2} \mathrm{O}$, (b) 1,10-phenanthroline monohydrate, (c) Acetamide, (d) Ethylenediamine, $\left[\mathrm{Co}(\mathrm{Phen})_{2}\left(\mathrm{H}_{2} \mathrm{O}\right)_{2}\right] \mathrm{Cl}_{2} . \mathrm{H}_{2} \mathrm{O}(1)$, (f) $\left[\mathrm{Co}(\mathrm{Phen})_{2}(\mathrm{Act})\left(\mathrm{H}_{2} \mathrm{O}\right)\right] \mathrm{Cl}_{2} \cdot \mathrm{H}_{2} \mathrm{O}(2)$, (g) $\left[\mathrm{Co}_{2}(\mathrm{Phen})_{4}(\mathrm{Act})_{2}\right.$ (en) $] \mathrm{Cl}_{4}(3)$, (h) $\left[\mathrm{Co}(\mathrm{Phen})_{2}\right.$ (Act)(en) $\mathrm{Cl}_{2}(4)$. 

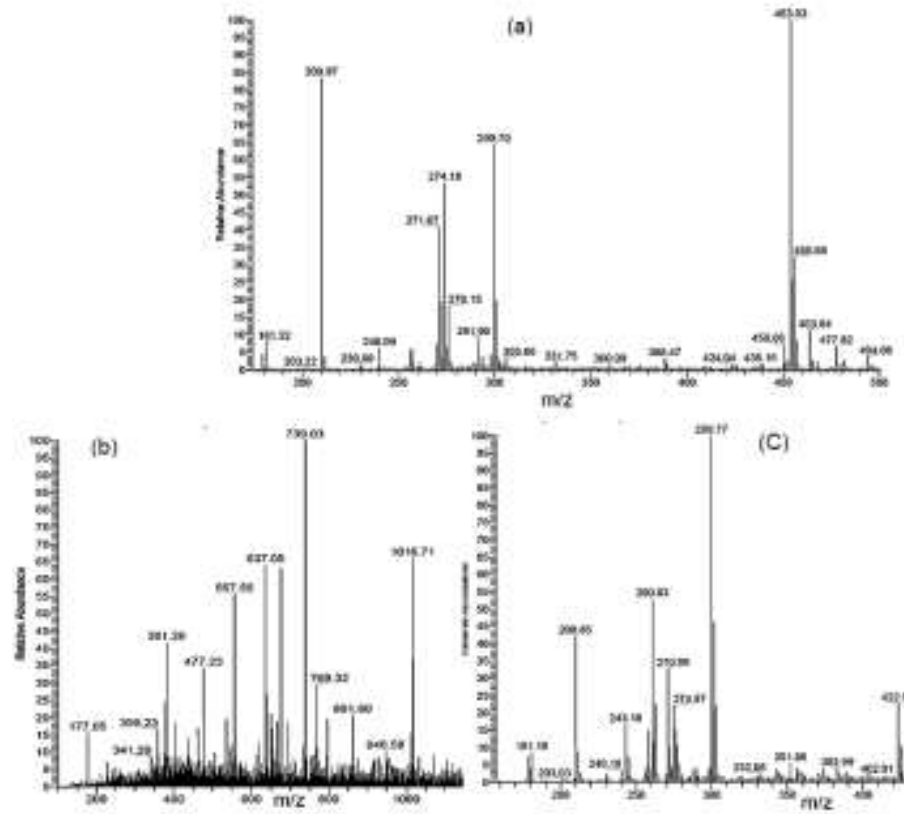

(C)

Figure 3. ESI MS spectra of (a) $\left[\mathrm{Co}(\mathrm{Phen})_{2}\left(\mathrm{H}_{2} \mathrm{O}\right)_{2}\right] \mathrm{Cl}_{2} . \mathrm{H}_{2} \mathrm{O}(1),(\mathrm{b})$ $\left[\mathrm{Co}_{2}(\mathrm{Phen})_{4}(\mathrm{Act})_{2}(\mathrm{en})\right] \mathrm{Cl}_{4}(3),(\mathrm{c})\left[\mathrm{Co}(\mathrm{Phen})_{2}(\mathrm{Act})(\mathrm{en})\right] \mathrm{Cl}_{2}(4)$. 


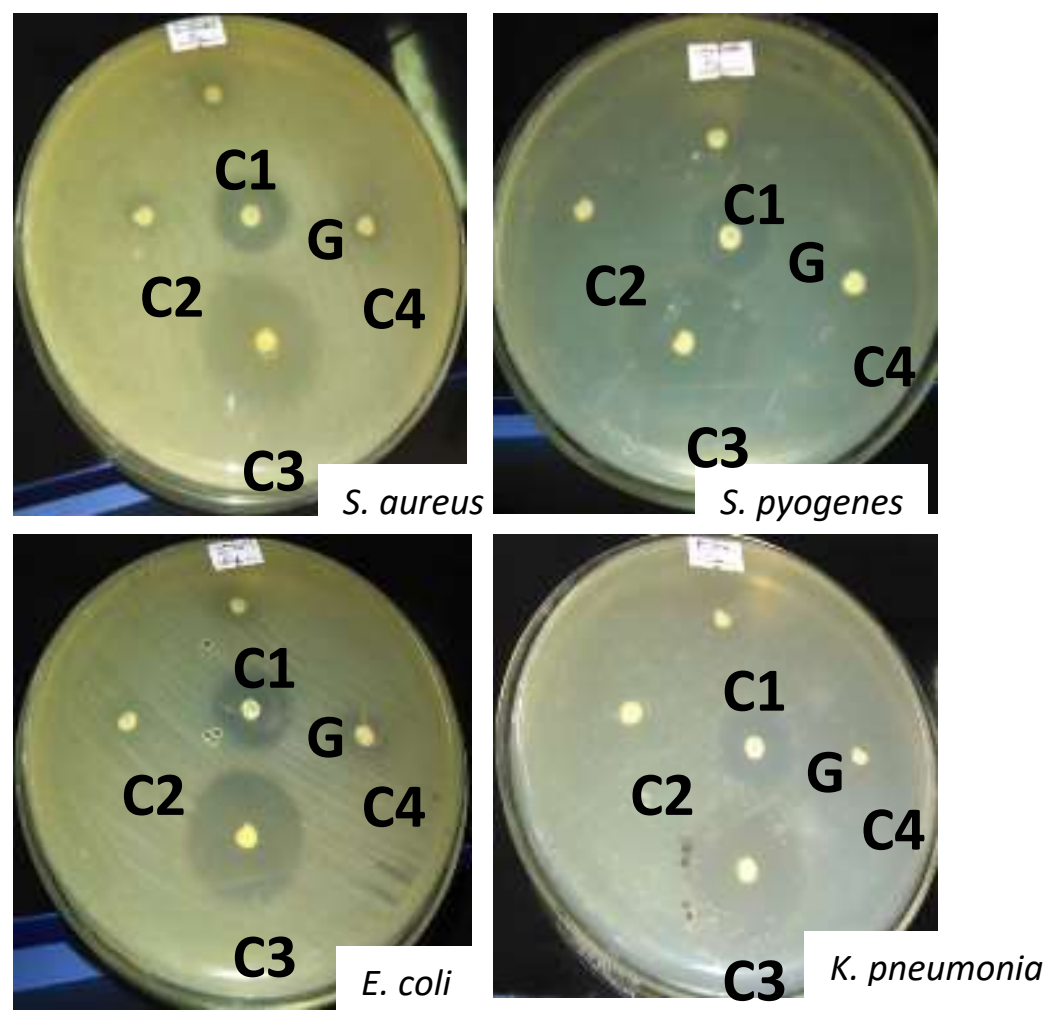

Figure 4. The inhibition observed by the actions of complexes and commercially available antibiotic on Gram-positive bacteria ( $S$. aureus and $S$. pyogenes) and Gram-negative bacteria (E. coli and K. pneumoniae). Where C1, C2, C3 and C4 stand for complex (1), (2), (3) and (4), respectively, and $\mathrm{G}$ is for Gentamicin.

\section{CONCLUSION}

In this work, two new mononuclear and one binuclear cobalt (II) complexes were synthesized. Based on various physical, chemical and spectroscopic investigations, octahedral geometry has been suggested for all synthesized complexes. In vitro antibacterial tests 
revealed that all the synthesized complexes exhibited antibacterial activity. Most Co (II) complexes are known to be active only against Gram-positive bacteria. However, the synthesized complexes showed awide-range of activities even against the Gram-negative bacteria $(E$. coli and $K$. pneumoniae). Thus, after in vivo cytotoxicity investigation, these complexes could be considered as a potential alternative antibiotic metal-based drugs.

\section{ACKNOWLEDGMENTS}

The authors express sincere gratitude to Bahir Dar University for financial support. We also thank Dr Belete Bedemo for running ESIMS at Academia Sinica, Institute of Chemistry, Taiwan.

\section{Competing Interests}

There is no conflict of interest among the authors and the funding institution.

\section{REFERENCES}

Atakilt Abebe and Tizazu Hailemariam (2016). Synthesis and assessment of antibacterial activities of ruthenium (III) mixed ligand complexes containing 1, 10-phenanthroline and guanide. Bioinorganic Chemistry and Applications, http://dx.doi.org/10.1155/2016/3607924.

Atakilt Abebe and Getinet Tamiru (2018). A hexacationic coordination compound from $\mathrm{Co}$ (II) and a cationic ligand derived from 4,4'-bipyridine: Synthesis, characterization and investigation for biological application. Cogent Chemistry 4(1): 1564162. https://doi.org/10.1080/23312009.2018.1564162

Al-Resayes, S.I., Shakir, M., Shahid, N., Azam, M and Khan, A.U. (2016). Synthesis, spectroscopic characterization and in vitro antimicrobial studies of Schiff base ligand, H2L derived from glyoxalic acid and 1, 8diaminonaphthalene and its $\mathrm{Co}$ (II), $\mathrm{Ni}$ (II), $\mathrm{Cu}$ (II) and $\mathrm{Zn}$ (II) complexes. Arabian Journal of Chemistry 9(3): 335-343.

Anjaneyulu, Y and Rao, R.P. (1986). Synthesis and antimicrobial studies of some metal complexes. Synthesis and Reactivity in Inorganic and MetalOrganic Chemistry 16: 257-261. 
Atkins, P.W. (1994). Physical Chemistry, Oxford University Press, Oxford, UK, $5^{\text {th }}$ edition.

Bencini, A and Lippolis, V. (2010). 1, 10-Phenanthroline: a versatile building block for the construction of ligands for various purposes. Coordination Chemistry Reviews 254(17-18): 2096-2180.

Bharathi Krishnan, R.V. (2016). Synthesis, characterization and study of biological applications of piperazine dithiocarbamate bridged homo binuclear mixed ligand complexes of Co (II) with amino acids. IOSR Journal of Applied Chemistry 9(6): 72-76.

Chandraleka, S., Ramya, K., Chandramohan, G., Dhanasekaran, D., Priyadharshini, A and Panneerselvam, A. (2014). Antimicrobial mechanism of copper (II) 1, 10-phenanthroline and 2, 2'-bipyridyl complex on bacterial and fungal pathogens. Journal of Saudi Chemical Society 18(6): 953-962.

Chang, E.L., Simmers, C and Knight, D.A. (2010). Cobalt complexes as antiviral and antibacterial agents. Pharmaceuticals 3(6): 1711-1728.

El-Reash, Y.G.A., Zaky, R and Yaseen, M.A. (2016). 2-(2-(2Hydroxybenzyliden) hydrazinyl)-2-oxo-n-(pyridine-2-yl) acetamide complexes: synthesis, characterization and biological studies. Chemical Sciences Journal 7: 145.

Feng, G., Shi, Y., Zhang, L., Shi, R., Huang, W and Wang, R. (2017). Airoxidation from sulfur to sulfone-bridged Schiff-base macrocyclic complexes showing enhanced antimicrobial activities. Scientific Reports 7(1): 15881 .

Gao, Y., van Belkum, M. J and Stiles, M.E. (1999). The outer membrane of gram-negative bacteria inhibits antibacterial activity of brochocin-C. Applied and Environmental Microbiology 65(10): 4329-4333.

Ghatole, A.M., Lanjewar, K.R and Gaidhane, M.K. (2012). Syntheses, characterization, antimicrobial activity of Copper (II), Zinc (II) and Cobalt (II) complexes of the bi-dented substituted 2-((E)-2-((2-chloro-6ethoxyquinolin-3-yl) methyleneamino) thiazol-4-yl) phenol having ON donor sites. Journal of Pharmacy Research 5(5): 2758-2762.

Golkar, Z., Bagasra, O and Pace, D.G. (2014). Bacteriophage therapy: a potential solution for the antibiotic resistance crisis. The Journal of Infection in Developing Countries 8(2): 129-136.

Gull, Y., Rasool, N., Noreen, M., Altaf, A.A., Musharraf, S.G., Zubair, M., and Zia-Ul-Haq, M. (2016). Synthesis of N-(6-Arylbenzo [d] thiazole-2acetamide derivatives and their biological activities: an experimental and computational approach. Molecules 21(3): 266.

Gurumoorthy, P., Ravichandran, J and Rahiman, A.K. (2014). Mixed-ligand binuclear copper (II) complex of 5-methylsalicylaldehyde and 2, 2'bipyridyl: Synthesis, crystal structure, DNA binding and nuclease activity. Journal of Chemical Sciences 126(3): 783-792. 
Hast, M.A., Fletcher, S., Cummings, C.G., Pusateri, E.E., Blaskovich, M.A., Rivas, K and Beese, L.S. (2009). Structural basis for binding and selectivity of antimalarial and anticancer ethylenediamine inhibitors to protein farnesyltransferase. Chemistry \& Biology 16(2): 181-192.

Housecraft, C.E and Sharpe, A.G. (2005). Inorganic Chemistry, Pearson Education, England, UK, $2^{\text {nd }}$ edition.

Iniama, G.E and Iorkpiligh, T. (2013). Synthesis, characterization and antimicrobial studies of Mn (II) Co (II) and Zn (II) Schiff base complexes derived from L-Arginine and 2-Hydroxy-1-Naphthaldehyde. International Journal of Science and Research 4(8): 979-982.

Kerridge, D.H. (1988). The chemistry of molten acetamide and acetamide complexes. Chemical Society Reviews 17: 181-227.

Khopkar, S.M. (1998). Basic concepts of analytical chemistry. New Age International.

Krishna, P.M., Shankara, B.S and Reddy, N.S. (2013). Synthesis, characterization, and biological studies of binuclear copper (II) complexes of (2E)-2-(2-Hydroxy-3-methoxybenzylidene)-4n-substituted hydrazinecarbothio- amides. International Journal of Inorganic Chemistry, http://dx.doi.org/10.1155/2013/741269.

Li, B and Webster, T.J. (2018). Bacteria antibiotic resistance: New challenges and opportunities for implant-associated orthopedic infections. Journal of Orthopaedic Research 36(1): 22-32.

Mahalakshmi, R and Raman, N. (2016). A therapeutic journey of mixed ligand complexes containing 1, 10-phenanthroline derivatives: a review. Chemistry 16: 1-6.

Nworie, F.S. (2016). Bis(salicylidene) ethylenediamine (salen) and bis (salicylidene) ethylenediamine-metal complexes: From structure to biological activity. Journal of Analytical \& Pharmaceutical Research 3: 76-85.

Panda, N., Tripathy, S.K., Behera, N.K., Panda, A.K., \& Das, P.K. (2015). Synthesis, spectroscopic and anti-microbial studies of binuclear Schiff base complexes derived from the ligand prepared from isoniazid and benzilmonohydrazone. International Journal of Innovative Science, Engineering \& Technology 2(4): 783-795.

Pasdar, H., Foroughifar, N and Hedayati Saghavaz, B. (2015). Investigation into the antibacterial activity of metal complexes derived from substituted chromone in comparison with tetracycline, and cephradine as standard drugs against Escherichia coli and Staphylococcus aureus. Journal of Medical Microbiology and Infectious Diseases 3(3): 75-79.

Patel, M.N., Chhasatia, M.R and Gandhi, D.S. (2009). Interaction of drug based binuclear mixed-ligand complexes with DNA. Bioorganic \& Medicinal Chemistry 17(15): 5648-5655. 
Podunavac-Kuzmanović, S.O., Leovac, V.M and Cvetković, D.D. (2008). Antibacterial activity of cobalt (II) complexes with some benzimidazole derivatives. Journal of the Serbian Chemical Society 73(12): 1153-1160.

Rafique, S., Idrees, M., Nasim, A., Akbar, H and Athar, A. (2010). Transition metal complexes as potential therapeutic agents. Biotechnology and Molecular Biology Reviews 5(2): 38-45.

Refat, M.S., El-Deen, I.M., Zein, M.A., Adam, A.M.A and Kobeasy, M. I. (2013). Spectroscopic, structural and electrical conductivity studies of Co (II), Ni (II) and $\mathrm{Cu}$ (II) complexes derived from 4-acetylpyridine with thiosemicarbazide. International Journal of Electrochemical Science 8(7): 9894-9917.

Saha, S., Dhanasekaran, D., Chandraleka, S and Panneerselvam, A. (2009). Synthesis, characterization and antimicrobial activity of cobalt metal complex against multi drug resistant bacterial and fungal pathogens. Facta Universitatis-series: Physics, Chemistry and Technology 7(1): 7380.

Shalash, A.M and Ali, H.I.A. (2017). Synthesis, crystallographic, spectroscopic studies and biological activity of new cobalt (II) complexes with bioactive mixed sulindac and nitrogen-donor ligands. Chemistry Central Journal 11(1): 40.

Stănilă, A., Braicu, C and Stănilă, S. (2011). Antibacterial activity of copper and cobalt amino acids complexes. Notulae Botanicae Horti Agrobotanici Cluj-Napoca 39(2): 124-129.

Getinet Tamiru Tigineh and Liu, L.K. (2014). Studies on mechanochemistry: solid coordination compounds from primary aromatic amines and cobalt (II) chloride hexahydrate. Journal of the Chinese Chemical Society 61(11): 1180-1187.

Tweedy, B.G. (1964). Plant extracts with metal ions as potential antimicrobial agents. Phytopathology 55: 910-914.

US Department of Health and Human Services. (2013). Antibiotic resistance threats in the United States, 2013. Centers for Disease Control and Prevention. Atlanta, GA, 114 p.

Ventola, C.L. (2015). The antibiotic resistance crisis: part 1: causes and threats. Pharmacy and Therapeutics 40(4): 277-283.

Warra, A.A. (2011). Transition metal complexes and their application in drugs and cosmetics-a Review. Journal of Chemical and Pharmaceutical Research 3(4): 951-958.

WHO (World Health Organization) (2012a). Promoting access to medical technologies and innovation: intersections between public health, intellectual property and trade. World Health Organization. Switzerland, $253 \mathrm{p}$ 
WHO (World Health Organization) (2012b) The evolving threat of antimicrobial resistance: options for action. World Health Organization, Geneva, Switzerland, $125 \mathrm{p}$.

WHO (World Health Organization). (2017). WHO publishes list of bacteria for which new antibiotics are urgently needed. WHO: Geneva, Switzerland; $7 \mathrm{p}$.

WHO (World Health Organization). (2018). Antibiotic resistance; Geneva, Switzerland; 86 